eventually leads to an anti-GQ1b immune response in the host and consequent neurological symptoms. Here we present the first example of a bacterial determinant associated with the pathogenesis of post-infectious acute immunemediated neuropathy. Although the circumstantial evidence is strong, it remains to be delineated whether this association translates into a causal relationship between cstII gene activity and GBS/MFS.

AleX VAN BELKUM ${ }^{1}$, NicOlE VAN DEN

Braak ${ }^{1}$, Peggy GodschalK ${ }^{1}$, Wim

ANG $^{1,2}$, BART JACOBS ${ }^{2}$, MiCHEL

GILBERT $^{3}$, WARREN WAKARCHUK ${ }^{3}$, Henri Verbrugh $^{1} \&$ Hubert ENDTZ ${ }^{1}$

${ }^{\prime} M e d i c a l$ Microbiology \& Infectious Diseases and

${ }^{2}$ Neurology and Immunology, Erasmus University
Medical Center Rotterdam, Rotterdam,

the Netherlands

${ }^{3}$ Institute of Biological Sciences, National Research Council of Canada, Ottawa, Ontario, Canada

Email:vanbelkum@bacl.azr.nl

1. Nachamkin, I., Allos, B.M. \& Ho, T. Campylobacter species and Guillain-Barré syndrome. Clin. Microbiol. Rev. 11, 555-567 (1998).

2. Moran, A.P., Appelmelk, B.M. \& Aspinall, G.O. Molecular mimicry of host structures by lipopolysaccharides of Campylobacter and Helicobacter spp.: Implications in pathogenesis. J. Endotoxin Res. 3, 521-531 (1996).

3. Kuroki, S. et al. Campylobacter jejuni strains from patients with Guillain-Barré syndrome belong mostly to penner serogroup 19 and contain $\beta$ - $N$-acetylglucosamine residues. Ann. Neurol. 33, 243-247 (1993).

4. Endtz, H.P. et al. Molecular characterization of C. jejuni from patients with Guillain-Barré and Miller Fisher syndrome. J. Clin. Microbiol. 38, 2297-2301 (2000).

5. Hartung, H.P., Van der Meché, F.G.A. \& Pollard J.D. Guillain-Barré syndrome, CDIP and other chronic immune-mediated neuropathies. Curr. Opin. Neurol. 11, 497-513 (1998).

6. Ang, C.W. et al. Structure of C. jejuni lipopolysaccharides determines anti-ganglioside specificity and clinical features of Guillain-Barré and Miller Fisher patients (In: PhD Thesis). (Erasmus University Rotterdam, Rotterdam, the Netherlands, 2001).

7. Sheikh, K.A. et al. C. jejuni lipopolysaccharides in Guillain-Barré syndrome: Molecular mimicry and host susceptibility. Neurology 51, 371-378 (1998).

8. Ang, C.W. et al. C. jejuni lipopolysaccharides from Guillain-Barré syndrome patients induce $\operatorname{lgG}$ antiGM1 antibodies in rabbits. J. Neuroimmunol. 104, 133-138 (2000)

9. Hood, D.W. et al. Sialic acid in the lipopolysaccharide of $\mathrm{H}$. influenzae: strain distribution, influence on serum resistance and structural characterization. Mol. Microbiol. 33, 679-692 (1999).

10. Guerry, P. et al. Sialylation of lipooligosaccharide cores affects immunogenicity and serum resistance of C. jejuni. Infect. Immun. 68, 6656-6662 (2000).

11. Gilbert, M. et al. Biosynthesis of ganglioside mimics in $\mathrm{C}$. jejuni $\mathrm{OH} 4384$ : identification of the glycosyltransferase genes, enzymatic synthesis of model compounds, and characterization of nanomole amounts by $600-\mathrm{MHz}{ }^{1} \mathrm{H}$ and ${ }^{13} \mathrm{C}$ NMR analysis. I. Biol. Chem. 275, 3896-3906 (2000).

\title{
Animal cloning experiments still banned in Italy
}

To the editor-A news story in the May issue of your journal that reports on worldwide legislation regarding human cloning (Nature Med., 7, 518; 2001) gives the impression that Italy has one of the most open and advanced policies in the world. This is far from the truth. In fact, an 'ordinanza' (legislative power used by the Ministry for urgent and temporary matters) has been in place since March 1997 banning "any experiment targeted directly or indirectly to human and animal cloning." This rule permits only the cloning of transgenic animals or endangered species assuming that cloning is a routine technique that does not require experimentation ${ }^{1}$.

In 1999, when our laboratory announced the cloning of Galileo (a bull obtained from blood cells ${ }^{2}$ ) we were charged with a criminal offence ${ }^{3}$, a verdict that was overturned six months later by a High Court Judge in Cremona who ruled that the ban on cloning was illegal. Although the scientific community had high hopes that the government would change its position on the matterHealth Minister Umberto Veronesi created a Commission headed by Renato Dulbecco that returned an open-minded report on cloning at the end of last year-nothing has changed. The 'ordi- nanza' banning cloning it is still in place and any scientist embarking on cloning experiments in Italy (animal and human) could still face criminal charges.

Cesare Galli \& Giovanna LazZari Laboratorio di Tecnologie della Riproduzione Consorzio Incremento Zootecnico

Cremona, Italy

Email: cegalli@tin.it

1. Gazzetta Ufficiale. n 55, 7 March (1997).

2. Galli, C. et al. Mammalian leukocytes contain all the genetic information necessary for the development of a new individual. Cloning 1, 161-170 (1999).

3. Simini, B. Italian scientist investigated after animal cloning experiment. Lancet 354, 1365 (1999).

\section{LETTERS TO THE EDITOR}

We want to hear from you! Nature Medicine is the forum for the latest, best, and most original biomedical research, news, and opinion. As such, we welcome letters from readers wishing to address topics reported on in previous issues, or subjects of interest to the biomedical research community at large. Letters should be brief and concise (no more than 500 words), and sent

to Nature Medicine, 345 Park Avenue South, New York NY 10010, USA, or sent by fax (212.683.5751) or email to medicine@natureny.com. 